DOI: $10.19195 / 0137-1169.37 .7$

ANNA WÓJCIUK

ORCID: 0000-0003-4712-3780

Uniwersytet Śląski w Katowicach, Polska

\title{
Analiza porównawcza haseł wyborczych polityków kandydujących na prezydenta Polski w 1990 i 2015 roku
}

\section{Wstęp}

Kampania wyborcza nie jest nowym zjawiskiem. Wyborcy są świadomi, że przed wyborami prezydenckimi, parlamentarnymi, samorządowymi środowiska polityczne prowadzą działania zachęcające do czynnego uczestnictwa w nich i oddania głosu na konkretną partię polityczną bądź polityka. Nie zawsze jednak polskie społeczeństwo miało prawo wyboru władz państwa. Po zakończeniu drugiej wojny światowej Związek Socjalistycznych Republik Radzieckich niektórym krajom, między innymi Polsce, narzucił komunistyczny system władzy, uniemożliwiający funkcjonowanie pluralizmu politycznego. W 1989 roku w Polsce nastąpił historyczny przełom - obalono rządy komunistyczne, zniesiono układ monopolu informacyjnego i monopolizację języka. Wprowadzono ustrój demokratyczny, a wraz z nim pluralizm polityczny, dzięki któremu zaczęto zakładać partie i ugrupowania polityczne ubiegające się o społeczne poparcie (por. Bralczyk 2003:67-70).

Przedmiotem mojego zainteresowania są hasła wyborcze kandydatów ubiegających się o urząd prezydenta Polski w wyborach prezydenckich przeprowadzonych w 1990 i 2015 roku¹. Przyglądając się warstwie językowej haseł, nietrudno zauważyć, że reprezentują one odmienne czasy, wartości i odwołania. Zmiana

${ }^{1}$ W wyborach prezydenckich przeprowadzonych w 1990 roku polscy obywatele mogli oddać swój głos na jednego z 6 kandydatów. O prezydenturę wówczas ubiegali się: Roman Bartoszcze, Włodzimierz Cimoszewicz, Tadeusz Mazowiecki, Leszek Moczulski, Stanisław Tymiński i Lech Wałęsa. W 2015 roku o urząd prezydenta starało się 11 kandydatów, byli to: Grzegorz Braun, Andrzej Duda, Adam Jarubas, Bronisław Komorowski, Janusz Korwin-Mikke, Marian Kowalski, Paweł Kukiz, Magdalena Ogórek, Janusz Palikot, Paweł Tanajno, Jacek Wilk, http://www.marketingwpolityce. 
tematów kampanii ujętych w hasłach jest związana z oczywistym dążeniem do politycznej aktualności. Hasło wyborcze ma bowiem wyrażać program odpowiadający obecnym potrzebom i odczuciom wyborców (por. Kochan 2002:85). W niniejszym opracowaniu, dokonując językowej analizy haseł wyborczych polityków kandydujących na prezydenta Polski w 1990 i 2015 roku, przedstawiłam reprezentowane przez hasła tendencje oraz opisałam techniki perswazyjne wzmacniające ich wydźwięk ${ }^{2}$.

\section{Istota kampanii wyborczej i znaczenie hasła wyborczego}

\subsection{Kampania wyborcza}

Wprowadzenie w Polsce ustroju demokratycznego przyczyniło się do powstania politycznej rywalizacji o społeczne poparcie. W tym celu wraz z każdymi nadchodzącymi wyborami prezydenckimi, parlamentarnymi i samorządowymi prowadzi się kampanie wyborcze będące „mechanizmem budowy pewnych form komunikowania podmiotów rywalizacji z obywatelami (wyborcami). Muszą być one efektywne politycznie i rozbudowane na skalę masową (aspekt organizacyjny i finansowy), treść i forma przesłania programowego zaś powinna być atrakcyjna i sprzedana w jak najlepszym »opakowaniu« (aspekt promocyjny)" (Dobek-Ostrowska/Wiszniowski 2002:149).

Pokazuje to, że kampanie wyborcze powinny być profesjonalnie zorganizowane, ponieważ z jednej strony służą przedstawieniu obywatelom programu politycznego, a z drugiej są narzędziem wpływu. Należy również zaznaczyć, że kampanie wyborcze są specyficzne, gdyż jak tłumaczy Dariusz Doliński: „Swoistość politycznych kampanii wiąże się między innymi z przeświadczeniem samych polityków o doskonałości własnych zamierzeń, programów, pomysłów na »lepszą« Polskę oraz o powszechnej akceptacji ich poglądów w społeczeństwie. O ile zatem producenci mydła, szamponu, czy lodówek doskonale wiedzą o różnych wadach tych artykułów, politycy sprawiają wrażenie przekonanych, że »obiektywnie« ich poglądy są bezbłędne i wyborcy na pewno je zaakceptują, jeśli tylko uda się do nich odpowiednio dotrzeć. Brak sukcesu wyborczego zawsze więc będzie winą źle przeprowadzonej kampanii” (Doliński 2010:241).

W celu przedstawienia programu politycznego, sylwetek kandydatów, ujawnienia wyznawanych przez nich poglądów, wartości i idei, zdobycia społecznego poparcia przedstawiciele partii politycznych i kandydaci na prezydenta prowadzą

zgora.pl/haslo.htm; http:/www.se.pl/wiadomosci/polityka/wszyscy-kandydaci-na-prezydentapolski-pelna-lista_584754.html (dostęp: 9.09.2017).

2 W niniejszym opracowaniu nie analizuję wszystkich haseł wyborczych. Przytaczam hasła prezentujące tendencje charakterystyczne dla kampanii prezydenckich prowadzonych w 1990 i 2015 roku. 
różne działania, na przykład organizują kampanie reklamowe, rozdają ulotki promocyjne, spotykają się z obywatelami; nie jest to działalność spontaniczna, lecz precyzyjnie zaplanowana. Bogusława Dobek-Ostrowska wyjaśnia, że: „profesjonalizacja komunikowania politycznego polega na przyswojeniu przez podmioty rywalizacji wyborczej oraz zastosowaniu w działaniu politycznym zespołu coraz bardziej przemyślanych i wyrafinowanych metod, stworzonych przez specjalistów z pogranicza świata nauki i praktyki politycznej, sprawdzonych naukowo oraz przetestowanych empirycznie" (Dobek-Ostrowska 2005:12).

Wraz z przełomem społeczno-polityczno-ekonomicznym nastąpiły zmiany w komunikacji środowisk politycznych ze społeczeństwem. Z użycia wyszły bowiem szablonowe, sztywne wypowiedzi, charakterystyczne dla przedstawicieli władz komunistycznych. Wprowadzono prosty język (także zwroty kolokwialne), choć nietrudno zauważyć dbałość o erudycję politycznych wypowiedzi, operowanie metaforami i środkami językowymi oddziałującymi na uczucia i emocje odbiorców (por. Bralczyk 2003:67-70).

\subsection{Hasło wyborcze}

Mówiąc o języku haseł wyborczych ${ }^{3}$, należy przede wszystkim odnotować, że powinny być one zwięzłe, wyraziste i sugestywne. Ich celem jest zachęcenie wyborców do zagłosowania na konkretnego kandydata, dlatego do stworzenia hasła odzwierciedlającego aktualne społeczne pragnienia i oczekiwania wykorzystywane są rozmaite językowe środki perswazyjne. Aby hasło wyborcze było skuteczne, powinno oddziaływać na wyobraźnię, odznaczać się atrakcyjnością i oryginalną formą językową, którą łatwo zapamiętać (por. Wiszniowski 1999:89).

W kampaniach prezydenckich prowadzonych w 1990 i 2015 roku kandydatów reprezentowały co najmniej dwa hasła. Jak wyjaśnia Marek Kochan, polityków może reprezentować jedno bądź kilka haseł wyborczych, choć, jak wskazuje badacz, „używanie jednego hasła jest pewnym ograniczeniem. Musi ono bowiem sprostać różnorodnym oczekiwaniom, powinno streszczać program polityczny, prezentować partię czy kandydata, wreszcie - zjednywać wyborców. Ponadto oferta polityczna jest adresowana do różnych grup elektoratu, co nie zawsze można zakomunikować jednym hasłem. Stąd pojawia się potrzeba równoległego używania kilku haseł" (Kochan 2002:86).

${ }^{3}$ Hasła wyborcze są elementem większego zjawiska, jakim jest reklama wyborcza stanowiąca niezbędny element każdej kampanii wyborczej. Badacze wskazują kilka celów reklamy wyborczej: wywołanie określonych zachowań poprzez propagowanie idei politycznych, prezentację w atrakcyjny, oryginalny i jasny sposób programów politycznych i kandydatów, pokazanie niezwykłych i wyróżniających ich cech (więcej na ten temat zob. Wiszniowski 1999:86-87). Ogólnie mówiąc, reklama polityczna pełni funkcję informacyjną i perswazyjną, przyciąga uwagę niezdecydowanych wyborców, umożliwia pokazywanie negatywnych cech przeciwników politycznych, modyfikuje i kształtuje postawy i zachowania (więcej na ten temat zob. Dobek-Ostrowska 2006:401). 
Ważną rolę w kampanii wyborczej odgrywa perswazja. Politycy kandydujący w wyborach prezydenckich, parlamentarnych i samorządowych, tworząc hasła wyborcze, korzystają z różnych środków perswazyjnych, ponieważ tego rodzaju techniki oraz figury stylistyczne i gramatyczne ,przydają tekstowi wiele efektów: rozjaśniają go, rozszerzają lub zawężają znaczeniowo, uplastyczniają i uwydatniają ideę, która w danym tekście ma być najważniejsza" (Kuśmierski 1996:137). Przyjrzyjmy się bliżej zjawisku perswazji.

\section{Perswazja w hasłach wyborczych}

Odnosząc zjawisko perswazji do komunikacji politycznej, można stwierdzić, że jest ono jednym z podstawowych mechanizmów demokracji opierającej się na poszanowaniu praw i obowiązków obywateli państwa demokratycznego. Charakterystycznymi cechami ustroju demokratycznego są: zdecentralizowana komunikacja, funkcjonowanie systemu kontroli władzy państwowej i samorządowej, planowanie i ustalanie działań na podstawie dyskusji. Czynniki te powodują, że między władzą a obywatelami zachodzi interakcja, prowadzony jest dialog, którego zasadniczym elementem jest właśnie perswazja (por. Kampka 2009:61).

Słowo perswazja pochodzi z języka łacińskiego, w którym persuasio oznacza przekonywanie odbiorcy za pomocą argumentacji podkreślającej słuszność zajmowanego stanowiska (por. Jachnis/Terelak 1998:220). Oznacza to, że zjawisko perswazji jest ściśle związane z nakłanianiem, namawianiem, zachęcaniem, przekonywaniem do podjęcia określonego działania. Zachowania polegające na nakłanianiu innych osób są wpisane w ludzką naturę, choć zmieniały się wraz z rozwojem cywilizacyjnym. Oddziałujące na odbiorcę i sprzyjające spełnieniu intencji nadawcy metody udoskonalano i nazwano technikami perswazyjnymi niezbędnymi w procesie komunikacji (por. Tokarz 2006:194). Perswazja jest obecna w komunikowaniu reklamowym, promocyjnym, politycznym itd. Ogólnie mówiąc, odnosi się ona „do tych aktów komunikacyjnych, których celem jest realizowanie strategii nakłaniających odbiorcę do określonego sposobu postępowania, zgodnego z intencjami osoby nadającej przekaz" (Albin 2000:110).

$\mathrm{Z}$ perswazją związany jest proces zmiany reprezentowanych postaw, wyznawanych przekonań, postępowania i zachowania osób, do których kierujemy perswazyjny komunikat (por. Tokarz 2006:194). Komunikowanie perswazyjne, będące podstawową techniką wpływu, służy: utrwaleniu postaw i zachowań, ich częściowej zmianie bądź kształtowaniu i utrwalaniu nowych, odmiennych postaw i zachowań (por. Filipiak 2003:36). Wpłynięcie na postawę odbiorcy jest zasadniczym zadaniem perswazji. Utrwalenie czy zastąpienie postawy inną nie jest łatwe, ponieważ ludzi cechuje stałość postaw i niechęć do jakichkolwiek zmian (por. Nadolska 2011:26). Aby intencja nadawcy komunikatu została spełniona, stosuje się najskuteczniejsze perswazyjne środki językowe, choć nie mogą one być skom- 
plikowane i trudne w interpretacji. Komunikat perswazyjny nabiera znaczenia tylko wtedy, gdy odbiorca rozumie intencję nadawcy i dobrowolnie podejmuje działania realizujące cel przekazu (por. Albin 2000:110-111).

Kampania wyborcza i reprezentujące kandydatów hasło wyborcze jest jedną z form perswazyjnej komunikacji polityków z obywatelami. Przyjrzyjmy się głównym myślom, które stały się zasadniczym budulcem haseł wyborczych kandydatów ubiegających się o urząd prezydenta Polski podczas pierwszych, powszechnych, wolnych i równych wyborów prezydenckich po obaleniu komunizmu oraz wyborów prezydenckich przeprowadzonych w 2015 roku$^{4}$.

\section{Hasła wyborcze polityków kandydujących na urząd prezydenta Polski w 1990 roku a strategie perswazyjne}

\subsection{Wpływ politycznego przełomu na kampanię prezydencką}

Analizując hasła wyborcze polityków starających się o najwyższy urząd w Polsce w 1990 roku, nietrudno zauważyć, że nawiązują one przede wszystkim do poprzedniego ustroju politycznego i polskiego społeczeństwa. Kandydaci poprzez hasła: krytycznie oceniali komunistyczne władze, wyrażali gotowość do wprowadzenia zmian, obiecywali prowadzenie racjonalnej polityki gwarantującej stabilność polityczną, ekonomiczną i gospodarczą, podkreślali szczególną rolę polskich obywateli w wyborach i procesie kształtowania przyszłości Polski, pokazywali, że wspólnie z polskim społeczeństwem tworzą jedną, spójną grupę, którą łączą te same problemy, potrzeby i pragnienia. Polityczne plany, obietnice i podkreślanie wartości polskiego społeczeństwa były związane z polityką obalonej w 1989 roku władzy komunistycznej. W czasach panującego komunizmu nie tylko wybór władz był niemożliwy. Komunistyczny rząd nie liczył się także z opinią społeczną, nie zwracał uwagi na potrzeby Polaków. Wraz z wprowadzeniem ustroju demokratycznego zmieniło się postrzeganie społeczeństwa. Środowiska polityczne skupiły na nim swoją uwagę, pokazując istotną rolę Polaków w rozwoju państwa. Dlatego też podczas kampanii prezydenckiej kandydaci podkreślali jedność z polskimi obywatelami, okazywali im szczególny szacunek oraz deklarowali, że społeczne pragnienia zostaną spełnione, a wszelkie problemy rozwiązane.

W kontekście polskich obywateli oraz krytyki systemu komunistycznego uwagę zwracają następujące hasła wyborcze: Jestem mądry Wasza mądrością; Jestem silny Wasza sita; Jestem jednym z Was; Znam Twoje problemy. Wiem, co zrobić i jak je rozwiazać; Mamy te same kłopoty. Pokonajmy je razem; Gtosuj

\footnotetext{
4 Hasła wyborcze kandydatów starających się o prezydenturę są dostępne w internecie: http://www. kampanianegatywna.pl/wybory/18-hasla-wyborcze-kandydatow-na-prezydenta-polski-1990-2015. html (dostęp: 9.09.2017).
} 
na mnie i na mój program; Nie ufaj elitom; Twój głos decyduje; Jego życiorys przemawia za nim; Nasz premier. Nasz prezydent. Poprzez wymienione hasła kandydaci: akcentowali mądrość, inteligencję, rozwagę, wytrwałość i waleczność Polaków, mówili o dużej wartości polskiego społeczeństwa, wskazywali jego istotną rolę $\mathrm{w}$ wyborze władz państwa, krytycznie wyrażali się o poprzednim systemie władzy, identyfikowali się z przeciętnymi obywatelami świadomymi negatywnych skutków komunistycznych rządów, nawiązywali do swojej antykomunistycznej działalności, mówili o konieczności naprawy kraju, która jest możliwa tylko przy pomocy obywateli.

\subsection{W poszukiwaniu wspólnych wartości - mechanizm wspólnoty świata i języka}

Aby silniej wpłynąć na wyborców, w hasłach zastosowano technikę wspólnoty świata i języka, która jest jedną z fundamentalnych kategorii wartościowania świata. Poczucie wspólnego języka i wspólnych wartości między nadawcą a odbiorcą ułatwia komunikację. Ponadto odbiorca szybciej akceptuje to, o czym ma pojęcie. Podchodzi wówczas do hasła pozytywnie, gdyż jego tematem są wartości przez niego wyznawane. Postawy, zachowania i wartości, których adresat przekazu nie zna bądź ich nie uznaje, są odrzucane. W ten sposób powstaje swoisty podział na to, co „swoje” i „obce”. Komunikat wyborczy odwołuje się do obu postaw. Zasadniczymi językowymi wykładnikami wspólnoty świata i języka są zaimki osobowe i dzierżawcze (por. Benedikt 2004:132-133). Należy podkreślić, że zaimki mogą być wyrażone na powierzchni tekstu, a także ukryte w formach czasownikowych.

$\mathrm{Z}$ analizy wynika, że w hasłach kandydatów ubiegających się o urząd prezydenta w 1990 roku najczęściej występują zaimek osobowy ty oraz zaimek dzierżawczy twój. Jest to uwarunkowane kilkoma zjawiskami. Pierwsze związane jest $\mathrm{z}$ obowiązującymi w czasach komunizmu formułami adresatywnymi. Bezpośredni zwrot do wyborców zastąpił formuły, którymi posługiwała się komunistyczna władza. Po zakończeniu drugiej wojny światowej rząd wprowadził formy obywatel, obywatelka. W oficjalnych rozmowach należało posługiwać się nowymi zwrotami adresatywnymi. Warto dodać też, że w Polskiej Zjednoczonej Partii Robotniczej funkcjonował zwrot towarzysz. Zarówno formuły obywatel, obywatelka, jak i towarzysz nie zyskały przychylności polskiego społeczeństwa (por. Łaziński 2006:41-43).

Drugie zjawisko odnosi się do kulturowego wyobrażenia o własnej osobie. Ludzie preferują bowiem traktowanie indywidualne, dlatego w hasłach dominuje zaimek ty (por. Bralczyk 2004:101-102). Nadawca hasła nigdy nie spotka się ze wszystkimi wyborcami, dlatego zaleca się, by tekst odnosił się bezpośrednio do jego adresata. W ten sposób zmniejsza się dystans nadawczo-odbiorczy (por. 
Dennison/Tobey 1994:56-57). Druga osoba liczby pojedynczej jest także formą charakterystyczną dla rozmowy wskazującej na bliskość partnerów konwersacji. Poza tym podkreśla ona wyjątkowość odbiorcy komunikatu oraz stanowi najprostszą i najbardziej sugestywną jego nazwę. Sugestywność jest pojęciem istotnym z perspektywy perswazji i wspólnoty świata i języka. Wyrażana przez bezpośredni zwrot do adresata, najczęściej w trybie rozkazującym, wywiera silny wpływ na odbiorcę, skłania go do refleksji (por. Bralczyk 2004:40 - 41, 101-102). Ponadto tryb rozkazujący w hasłach pełni funkcję obrazująco-emocjonalną. Jego celem jest wyeksponowanie dobrych intencji nadawcy hasła oraz wyrażenie troski o dobro odbiorców (por. Benedikt 2004:120).

\subsection{Identyfikacja ze społeczeństwem i krytyka komunizmu - znaczenie opozycji ,my-oni”}

W kontekście utożsamiania się kandydatów z polskimi obywatelami ważną rolę odgrywa opozycja „my-oni”. W czasach postkomunistycznych znaczenie „my” uległo zmianie. Komunistyczna władza tworzyła fikcyjne, narzucone porozumienie z polskim społeczeństwem, sztucznie używała zaimka „my”, który obejmował władzę i obywateli. Po przełomie pojawiło się nowe „my” oznaczające wspólnotę polskiego społeczeństwa i polityków walczących z ustrojem komunistycznym (por. Bralczyk 2003:73).

Podczas pierwszych wyborów prezydenckich po obaleniu komunizmu opozycja „my-oni” była zasadniczym motywem kampanii i innych działań o charakterze politycznym. Dokładnie określono, kto należy do „swoich”, a kto do grupy „obcych”. Katarzyna Kłosińska wskazuje, że po 1989 roku „my”, a więc: prawdziwi Polacy, prawdziwa Solidarność, patrioci, to reprezentacja społeczeństwa oczekującego na zmiany, osoby zdolne do poświęceń dla dobra ojczyzny i obywateli, z kolei „oni” to: komuniści, czerwoni, spiskowcy, zdrajcy będący zagrożeniem dla kraju i polskiego społeczeństwa. Badaczka notuje, że opozycję „my-oni” wykorzystywały prawicowe i lewicowe środowiska polityczne rywalizujące o poparcie społeczne (por. Kłosińska 2004:115-121). Potwierdza to hasło: Zbyt dtugo było w lewo. Zbyt ostro chce być w prawo. Z przytoczonego hasła jasno wynika, że kandydat nie popiera zarówno poprzedniej władzy, jak i konkurentów o prawicowych poglądach.

\subsection{Jestem taki jak ty - rola techniki podobieństwa w kampanii wyborczej}

Zauważmy, że w hasłach: Jestem jednym z Was; Mamy te same kłopoty. Pokonajmy je razem; Mieszkańcy wsi - głosujcie na rolnika, działacza PSL $i$,, Solidarności” Rolników Indywidualnych Romana Bartoszcze kandydaci prezentowali się 
jako osoby pod pewnymi względami podobne do wyborców. Zabieg ten wzmacnia poczucie przynależności do danej zbiorowości. Z obrazu zawartego w hasłach wynika, że kandydaci tak samo jak wyborcy są częścią polskiego społeczeństwa, nic szczególnego ich nie wyróżnia, są przeciętnymi obywatelami, nie należą do elit, mają podobne obowiązki i trudności, z którymi muszą mierzyć się na co dzień, pracują zawodowo, są zaangażowani w działalność określonych organizacji, zajmują się między innymi rolnictwem.

Wskazywanie podobieństwa między kandydatami a wyborcami jest charakterystyczne dla techniki podobieństwa. Elementami wspólnymi mogą być na przykład cechy fizyczne, doświadczenie życiowe, styl życia (por. Doliński 2010:265). Technika ta silnie oddziałuje na odbiorców. Połączona z mechanizmem wspólnoty świata i języka sprawia bowiem, że pojawia się tak zwany efekt bliskości między nadawcą a odbiorcą (por. Jachnis/Terelak 1998:233). Nie jest istotne, czy podobieństwo będzie obejmowało cechy charakteru, doświadczenie życiowe, wyznawane poglądy i wartości, czy styl życia. Ogólnie mówiąc, ta technika perswazyjna sprawia, że odbiorca obdarza nadawcę hasła sympatią (por. Cialdini 1999:161-162). Umiejętność wzbudzenia sympatii odgrywa szczególną rolę w perswazji. Jeżeli odbiorca polubi nadawcę przekazu, wówczas wypowiedziane przez niego słowa będą bardziej perswazyjne (por. Jachnis/Terelak 1998:232-233). Jest to spowodowane tym, że sympatia z nadawcy przekazu przenosi się też na propagowaną przez niego ideę.

\subsection{Wpłynąć na wyobraźnię wyborców - istota porównania}

Wzbudzaniu sympatii (niekiedy niechęci), poczucia wspólnoty i uwypukleniu opozycji „my-oni” służy też porównanie. Zastosowane w haśle sprawia, że poszerza się semantyka przekazu, a użyte słowa nabierają nowego znaczenia (por. Kuśmierski 1996:135-136).

W hasłach kandydatów występują porównania służące wartościowaniu w sensie zarówno pozytywnym, jak i negatywnym. W haśle: 1920 - Witos wzywa do oręża/ 1990 - niech Bartoszcze znów zwycięża poprzez przywołanie nazwiska działacza ruchu ludowego, współzałożyciela Polskiego Stronnictwa Ludowego i premiera Polski zastosowano porównanie wartościujące pozytywnie, którego funkcja polega na subtelnym utożsamieniu i podnoszeniu wartości porównywanej osoby (por. Murdoch 2004:114). Ponadto, jak wskazuje Anna Kowal-Orczykowska, ,porównania stanowią szybką i często stosowaną technikę, która błyskawicznie przywołuje w wyobraźni odbiorcy oczekiwane skojarzenia [...]. Pozytywne asocjacje powstałe na bazie udanego porównania będą silnie wpływały na proces decyzyjny odbiorców" (Kowal-Orczykowska 2010:59-60).

Spójrzmy również na hasło, w którym zastosowano porównanie służące wartościowaniu w sensie negatywnym: Zbyt dlugo byto w lewo. Zbyt ostro chce być w prawo. Poprzez nie kandydat ubiegający się o urząd prezydenta zmniejszył war- 
tość poprzedniej władzy oraz pozostałych kandydatów. W przytoczonym haśle nie ujawniono nazwisk, w pośredni sposób poinformowano wyborców, na kogo nie warto zagłosować. W komunikatach, w których dokonuje się pośredniego porównania, nie pojawia się nazwisko konkurenta ani nazwa przedmiotu, zjawiska itp. Adresatom przekazu w niejednoznaczny sposób daje się do zrozumienia, jaka osoba, rzecz, zjawisko jest przedmiotem porównania (por. Barańska 2011:123). Dobek-Ostrowska thumaczy, że podczas kampanii wyborczej politycy nie tylko przedstawiają pozytywne cechy swoich programów wyborczych, kreują się na osoby godne zaufania, lecz także deprecjonują kontrkandydatów. Zdaniem badaczki ,przekazy polityków koncentrują się na zaletach kandydata (reklama pozytywna) lub na wadach przeciwnika politycznego (reklama negatywna), na programie partii lub kandydata, mogą także zestawiać i porównywać w dowolnej konfiguracji uczestników walki wyborczej (reklama porównawcza)" (Dobek-Ostrowska 2006:381).

Zauważmy, że hasło Zbyt dlugo było w lewo. Zbyt ostro chce być w prawo jest również przestrogą dla odbiorców przekazu. Kandydat starający się o prezydenturę pragnął pokazać wyborcom, że ich decyzja może przynieść negatywne skutki.

\subsection{Wybierz mnie, a dużo zyskasz - wpływ metody pokazywania korzyści na wynik wyborów prezydenckich}

W związku z przełomem polscy obywatele oczekiwali zmian. Pragnęli, by władze demokratyczne zapewniły im bezpieczeństwo, możliwość rozwoju i stabilność. Dlatego kandydaci starający się o urząd prezydenta poprzez hasła wyborcze pokazywali korzyści, jakie Polacy mogą uzyskać dzięki zagłosowaniu na nich, i przedstawiali idee polityczne, które były społecznie pożądane. Spójrzmy na następujące przykłady: Bezpieczeństwo żywnościowe i ekologiczne to program lidera PSL; Socjalne bezpieczeństwo, demokracja parlamentarna to Cimoszewicz; Rozsadek nad emocjami; Konieczność przełomu; I z zachodem i ze wschodem, ale głównie z własnym narodem; Znam Twoje problemy. Wiem, co zrobić i jak je rozwiazać; Przywrócić godność $i$ szacunek Rzeczypospolitej; Uparcie do przodu. Z haseł wynika, że po wygranych wyborach prezydent otoczy polskich obywateli szczególną opieką. Umożliwi to prowadzona przez niego polityka, która będzie opierać się na: sprawowaniu rządów zgodnych z zasadami demokracji, rozwoju polskiej gospodarki, ochronie środowiska, bezpieczeństwie ekonomicznym, racjonalnym i odpowiedzialnym podejmowaniu decyzji, podnoszeniu wartości polskiego społeczeństwa i zaspokojeniu jego materialnych potrzeb, rozwiązaniu wszelkich problemów i niedogodności związanych z poprzednią władzą, wprowadzeniu zmian, dzięki którym polskie państwo będzie lepiej funkcjonować, co zapewni stabilność i porządek w kraju.

Badacze Dell Dennison i Linda Tobey podkreślają, że hasła pokazujące korzyści oddziałują głównie na uczucia i emocje adresatów przekazu, zachęcają ich 
do realizacji celu nadawcy (por. Dennison/Tobey 1994:52-54). W zamierzeniu kandydatów ubiegających się o urząd prezydenta Polski podczas pierwszych wolnych wyborów po obaleniu komunizmu zapewnienia dotyczące stabilizacji sytuacji politycznej kraju, rozwoju państwa i bezpieczeństwa miały wywoływać u wyborców pozytywne uczucia i emocje, które z kolei powinny wpłynąć na powstanie pozytywnych skojarzeń związanych z nadawcą hasła.

\section{Hasła wyborcze polityków kandydujących na prezydenta Polski w 2015 roku a techniki perswazyjne}

\subsection{Globalizacja a kampania prezydencka}

Postępująca globalizacja spowodowała, że współczesne kampanie wyborcze mają inny charakter. Rozwijający się rynek międzynarodowy, coraz większe udziały zagranicznych podmiotów w funkcjonowaniu państwa, powstanie ,globalnej wioski", powolny zanik kulturowych różnic przyczyniły się bowiem paradoksalnie do wzrostu znaczenia własnej ojczyzny, więzi narodowych i uczuć patriotycznych. Obecnie podczas kampanii wyborczych podkreśla się, że najważniejszy jest rozwój i podniesienie znaczenia ojczyzny. Tendencję tę reprezentują hasła kandydatów ubiegających się o urząd prezydenta Polski w 2015 roku: Przyszłość ma na imię Polska; Godne życie w bezpiecznej Polsce; Potrafisz Polsko!; Dumna, bogata Polska; Polska od nowa; Aby Polska nie zginęta; Poważnie o Polsce.

Nietrudno zauważyć, że hasła służą wyeksponowaniu Polski, co z kolei oddziałuje na emocje wyborców. Nazwa ojczyzny jest słowem emocjonalnym, poruszającym w odbiorcy głębokie uczucia, wspomnienia i skojarzenia. Słowa oddziałujące na emocje nie wymagają dodatkowych informacji i opisów, ponieważ one same są perswazyjne i pojemne znaczeniowo (por. Kowal-Orczykowska 2010:60-61). To pokazuje, że kluczem interpretacyjnym haseł kandydatów starających się o prezydenturę w 2015 roku jest słowo Polska. Wyborcy, przywołując skojarzenia związane z ojczyzną, odczytywali hasła indywidualnie, zgodnie $\mathrm{z}$ własnymi przekonaniami. To sprawiło, że jedno hasło było różnie interpretowane. Dla przykładu przyjrzyjmy się hasłu Polska od nowa, które bezpośrednio komunikuje wyborcom, że celem kandydata jest wprowadzenie wielu zmian w polityce kraju. Sugeruje nam to wyrażenie od nowa, które podobnie jak przymiotnik nowy jest jednym z kluczowych słów w tekstach perswazyjnych ${ }^{5}$. Kierunek zmian nie jest jednak określony, umożliwia to szeroką interpretację hasła. $\mathrm{W}$ ten sposób obywatele, dla których najważniejsze jest bezpieczeństwo, hasło

\footnotetext{
5 Przymiotnik nowy nie zawsze miał pozytywne konotacje. W latach 1982-1989 słowo nowy było nacechowane negatywnie; było to związane z władzą komunistyczną, która sztucznie zamieniała nowym bardziej szlachetne starsze (więcej na temat zob. Bralczyk 2004:65).
} 
Polska od nowa wyjaśniali w kontekście polityki bezpieczeństwa, członkowie społeczeństwa stawiający na pierwszym planie zdrowie odczytywali je w odniesieniu do poprawy polityki zdrowotnej, wyborcy pragnący stabilizacji finansowej tłumaczyli je w kontekście zmian w zakresie polityki zatrudnienia i finansów, z kolei członkowie społeczeństwa czujący silną więź z rodziną interpretowali hasło w nawiązaniu do polityki prorodzinnej i socjalnej, odbiorcy uważający, że najważniejsza jest pozycja Polski na arenie międzynarodowej wiązali hasło ze zmianami w polityce zagranicznej itd.

\subsection{Zaintrygować wyborców i skłonić ich do refleksji- personifikacja jako mechanizm perswazyjny}

W kontekście interpretacji powiązanej z ojczyzną i jej obywatelami uwagę szczególnie przykuwają hasła: Potrafisz Polsko!; Przyszłość ma na imię Polska oraz Dumna, bogata Polska. Forma językowa sprawia, że można je odnieść zarówno do kraju, jak i jego obywateli. Słowo Polska może być bowiem rozumiane jako jednostka terytorialna bądź społeczeństwo - obywatele kraju.

Odnosząc przytoczone hasła do państwa, można wywnioskować, że zastosowano w nich personifikację przyciągającą uwagę odbiorców i wzbudzającą zainteresowanie. Za pomocą tego zabiegu hasła stały się interesujące i zachęcały do interpretacji. W tym kontekście hasło Potrafisz Polsko! pokazywało, że kraj może się rozwijać mimo trudnych doświadczeń; Przyszłość ma na imię Polska zapowiadało silną pozycję kraju na arenie międzynarodowej; z kolei Dumna, bogata Polska mówiło o podniesieniu prestiżu ojczyzny, zdobyciu bogactwa w różnych dziedzinach, na przykład finansowej, kulturowej itp. Zdaniem Karoliny Janiszewskiej i Jacka Kalla twórcy haseł coraz częściej sięgają po personifikację „w poszukiwaniu nowych form wyrazu, chcąc zwrócić uwagę audytorium, zniekształca się obraz rzeczywistości, który staje się przez to w pewien sposób intrygujący i ciekawy. Do powszechnie stosowanych technik należą: hiperbolizacja - polegająca na wyolbrzymianiu rzeczywistości, minimalizacja - prezentacja rzeczywistości w pomniejszeniu, oraz personifikacja [wyr. — oryg.] - przedstawianie przedmiotów nieożywionych jako żywe" (Janiszewska/Kall 2012:42).

Analizując wskazane przykłady w odniesieniu do polskiego społeczeństwa, można natomiast stwierdzić, że hasło Potrafisz Polsko! mówi o dokonywaniu przez polskich obywateli właściwego wyboru, efektywnym prowadzeniu działań, które wydają się niemożliwe do wykonania. Z kolei Przyszłość ma na imię Polska dotyczy dzieci i młodego pokolenia Polaków. Poprzez to hasło kandydat pragną pokazać, że ważne są dla niego nie tylko osoby mające prawo głosu w wyborach, lecz także dzieci i młodzież. Hasło Dumna, bogata Polska pokazuje natomiast, że po wygranych wyborach kandydat zapewni polskiemu społeczeństwu dobrobyt w różnych sferach życia oraz poczucie godności i wartości. 


\subsection{Podział na „swoich” i „obcych” - znaczenie mechanizmu wspólnoty świata i języka w kampanii prezydenckiej}

Czytając hasła polityków biorących udział w wyborach prezydenckich w 2015 roku, można wysunąć wniosek, że zastosowano w nich mechanizm wspólnoty świata i języka. Kandydaci poprzez hasła uświadamiali wyborcom, że do grupy „swoich" należy to, co jest związane z państwem polskim, a więc: ojczyzna, polscy obywatele, symbole narodowe, polska tradycja i kultura. Celem tego mechanizmu było wzbudzenie w polskich obywatelach uczuć patriotycznych, poczucia przywiązania do ojczyzny, odpowiedzialności za Polskę, obowiązku uczestnictwa w wyborach i oddania głosu na tego kandydata, który podkreśla, że ojczyzna stanowi dla niego szczególną wartość.

W kontekście podziału na „swoich” i „obcych” warto zwrócić uwagę na hasło Aby Polska nie zginęła. Zauważmy, że jest ono aluzją. Nawiązuje bowiem do polskiego hymnu narodowego - Mazurka Dąbrowskiego autorstwa Józefa Wybickiego, będącego początkowo pieśnią zagrzewającą do walki o ojczyznę. Zabieg ten sprawił, że hasło jest treściwe, bogate w konotacje i odwołania kulturowe. Poprzez nie kandydat nawiązał do patriotyzmu, motywu walki o wolność, bohaterstwa, dokonywania wielkich czynów, poświęcania się dla dobra kraju. Hasło Aby Polska nie zginęła szczególnie oddziaływało na Polaków cechujących się patriotyzmem. Tego typu osoby często rozmawiają o polskich działaniach narodowowyzwoleńczych, są także przekonane o odwadze i moralności polskiego narodu (por. Łysakowski 2005:36). Korzystanie z powszechnie znanych motywów, dzieł, postaci literackich, filmowych, muzycznych czy patriotycznych wzmacnia perswazję przekazu oraz ułatwia kategoryzację świata i podział na „swoich” i „obcych” (por. Lewiński 2008:136).

\subsection{Podkreślanie narodowej jedności - funkcja „efektu bliskości”}

Z mechanizmem wspólnoty świata i języka wiąże się wspomniany „efekt bliskości" mający emocjonalny charakter. Istotą tego zjawiska jest wywołanie u odbiorcy poczucia pewnego związku bądź nawet identyfikacji z nadawcą hasła. Aby jednak było to możliwe, kandydat musi pokazać, jakie spoiwo łączy go z wyborcami (por. Łysakowski 2005:8). W kampanii wyborczej prowadzonej w 2015 roku spoiwem była ojczyzna, która tworzyła zarówno atmosferę jedności z kandydatem, jak i poczucie wspólnoty narodowej i kulturowej.

Współczesne zmagania $\mathrm{z}$ dominacją języka angielskiego oraz napływ europejskich i amerykańskich zwyczajów sprawiają, że wszelkie nawiązania do narodowej jedności i wartości ojczyzny przejawiają moc perswazyjną i najczęściej są pozytywnie odbierane (por. Bralczyk 2004:135). Doliński wskazuje, że ludzie chętniej kupują towary produkowane we własnym kraju. W dobie międzynarodo- 
wych korporacji i zanikania firm narodowych preferujemy rodzime produkty (por. Doliński 2010:209-212). To sprawia, że odwoływanie się do patriotyzmu jest szczególnie ważne w kampanii prezydenckiej. Osoba piastująca najwyższy urząd w państwie powinna pokazać społeczeństwu, że dbanie o kraj jest jej zasadniczym celem, dlatego politycy kandydujący na urząd prezydenta Polski przekonywali wyborców, iż ojczyzna jest dla nich najważniejsza.

\subsection{Niezmienny element kampanii wyborczej - pokazywanie korzyści}

Jak wynika z dotychczasowych rozważań, hasła kampanii prezydenckiej prowadzonej w 2015 roku odwoływały się do różnych korzyści. Kandydaci zapewniali wyborców, że po wygranych wyborach będą pielęgnować polskie tradycje, obyczaje i zwyczaje. Podkreślanie wszelkich korzyści i składanie obietnic stanowi podstawę działalności politycznej, gdyż, jak wyjaśnia Agnieszka Kampka, wyróżnia się trzy źródła politycznego zaangażowania polityków: ,„po pierwsze - poczucie odpowiedzialności za kraj i współobywateli oraz wynikające z niego pragnienie pracy na ich rzecz. Drugim powodem jest wierność ideałom i wartościom, które wymagają umocnienia lub obrony. Trzeci wreszcie motyw skłaniający polityka do działania to chęć urzeczywistnienia określonej wizji służącej wspólnemu dobru" (Kampka 2009:148).

\section{Podsumowanie}

Podsumowując, z przeprowadzonej analizy wynika, że kandydaci ubiegający się o prezydenturę w 1990 i 2015 roku odwoływali się do odmiennych zjawisk, kwestii i zagadnień. Politycy tuż po polityczno-społeczno-ekonomicznym przełomie musieli zmierzyć się z poważnym problemem, którym było przeświadczenie społeczeństwa o manipulacyjnym charakterze komunikacji politycznej. W czasach komunistycznych manipulacja była nieodłącznym elementem komunikacji władzy ze społeczeństwem, co oczywiście wpłynęło na postrzeganie kampanii wyborczych. Jak tłumaczy Jerzy Bralczyk, „,początkowy odbiór kampanii był zdeterminowany wieloma uwarunkowaniami: [...], nastawieniem na informacyjno-propagandową funkcję mediów, głównie telewizji; stosunkiem do zdewaluowanego komunikowania propagandowego, którego społecznie nieoczywista konwencjonalność ujawniła w gruncie rzeczy zakłamaną, prymitywną i naiwną manipulację" (Bralczyk 2004:138).

Kandydaci ubiegający się o urząd prezydenta w 1990 roku musieli pokazać wyborcom, że ich kampania jest prowadzona zgodnie z zasadami demokracji, odmiennymi od reguł komunistycznych. Politycy zatem przekonywali polskie spo- 
łeczeństwo o zamiarach prowadzenia polityki opartej na stabilizacji politycznej, gospodarczej i ekonomicznej kraju oraz dialogu ze społeczeństwem. Odzwierciedlały to hasła wyborcze, w których negatywnie określano komunistyczny system władzy i podkreślano dużą wartość polskich obywateli w kształtowaniu polityki państwa i jego dalszym rozwoju. Podczas ostatnich wyborów prezydenckich, w dobie globalizacji, amerykanizacji oraz europeizacji stylu życia i zwyczajów, coraz wyraźniejszego mieszania się kultur i zaniku narodowych tradycji, kandydaci poruszali kwestie narodowe. Tłumaczyli wyborcom, że najważniejszy jest interes państwa i jego obywateli oraz pielęgnowanie narodowych tradycji i wartości.

Należy jednak podkreślić, że kampanie wyborcze ewoluują. Robert Wiszniowski wskazuje bowiem, że współcześnie „zauważa się przede wszystkim rozwój form »sprzedaży« polityków, rosnącą rolę "przywództwa« w elekcjach. Politolog L. Sabato zaczął postrzegać doniosłe znaczenie i rolę politycznych konsultantów w procesie prowadzenia, a szczególnie kreowania określonych modeli kampanii wyborczych" (Wiszniowski 1999:87).

Zjawisko to nosi nazwę ,amerykanizacji kampanii wyborczej”. Jej istotą jest przejmowanie przez europejskie środowiska polityczne amerykańskich wzorów kampanii politycznych - zwiększa się działania promocyjne, coraz częściej korzysta ze środków masowego przekazu oraz prowadzi działania o charakterze marketingowym (por. Wiszniowski 1999:87-88). Ponadto wyborcom przedstawiany jest nie tylko program wyborczy kandydatów, szczególną uwagę zwraca się także na ich wizerunek będący integralną częścią struktury dyskursu politycznego (por. Jeziński 2005:115-132). W tym celu regularnie przeprowadzane są sondaże pokazujące, jakie cechy powinien mieć polityk. Z badań wynika, że wyborcy najlepiej postrzegają polityków, którzy są: odpowiedzialni, rzetelni, kompetentni, konsekwentni, pracowici, uczciwi, roztropni, otwarci na dialog, wykonujący swoją pracę profesjonalnie i skutecznie (por. Kampka 2009:152).

Można jednak wskazać elementy niezmienne w kampanii wyborczej. Kampka podkreśla, że każdy kandydat na prezydenta bądź partia polityczna biorąca udział w wyborach przekonuje wyborców o zmianie stylu rządzenia, przeprowadzeniu wielu reform, przyspieszeniu rozbudowy kraju i jego modernizacji. Ponadto kandydaci zapewniają obywateli, że ich polityczna działalność nie wykroczy poza demokratyczne zasady, a więc wszelkie zapowiadane zmiany będą konsultowane ze społeczeństwem. Jeżeli nie będzie społecznej aprobaty, nie zostaną wprowadzone, ponieważ, jak przekonują politycy, władza ma służyć obywatelom, spełniać ich oczekiwania. Politycy zawsze gwarantują też zwiększenie aktywności obywatelskiej oraz częsty dialog władzy ze społeczeństwem. Poza tym wielokrotnie obiecuje się wyborcom, że po objęciu władzy rząd będzie działał szybciej, sprawniej, bardziej odpowiedzialnie i uczciwie niż poprzedni (por. Kampka 2009:115-125).

Wybory prezydenckie przeprowadzone w 1990 roku wymagały dwóch tur głosowania. W pierwszej największe poparcie uzyskali Lech Wałęsa, na którego zagłosowało 39,9\% Polaków, oraz Stanisław Tymiński z poparciem 23,10\%. 
W drugiej turze 74,3\% głosów zdobył Lech Wałęsa, zostając tym samym pierwszym prezydentem Polski po obaleniu komunizmu6. Polityka reprezentowały hasła: Jestem mądry Wasza mądrością; Jestem silny Waszą siłą; Jego życiorys przemawia za nim. Wybory prezydenckie z 2015 roku również wymagały przeprowadzenia dwóch tur głosowania. W pierwszym głosowaniu największe poparcie uzyskali Andrzej Duda i Bronisław Komorowski. Kandydat Prawa i Sprawiedliwości zdobył 34,76\% głosów, reprezentant Platformy Obywatelskiej z kolei $33,77 \%{ }^{7}$. Ponowne głosowanie sprawiło, że prezydentem Polski został Andrzej Duda, na którego zagłosowało $51,55 \%$ polskich obywateli ${ }^{8}$. Polityka reprezentowały trzy następujące hasła wyborcze: Przyszłość ma na imię Polska; Godne życie w bezpiecznej Polsce; Dobra zmiana.

Nietrudno jednak zauważyć, że jednym z głównych problemów wyborów władz państwowych i samorządowych jest niska frekwencja wyborcza. Politycy kandydujący w wyborach oraz specjaliści od kampanii wyborczych niejednokrotnie zastanawiają się, jak zachęcić obywateli, by wzięli udział w wyborach. Anthony Greenwald wraz ze współpracownikami przeprowadził eksperyment pokazujący, w jaki sposób można wpłynąć na frekwencję wyborczą 9 . Z przeprowadzonych badań wynika, że środowiska polityczne powinny zaangażować grupę osób, której zadaniem byłoby telefonowanie do wyborców kilka dni przed wyborami z pytaniem o uczestnictwo w wyborach. Osoby, które zadeklarują udział w wyborach, odczują obowiązek oddania głosu na danego kandydata i rzeczywiście pójdą zagłosować (por. Doliński 2010:258). W Polsce jeszcze nie posłużono się tą metodą nakłaniającą do głosowania, choć nie można powiedzieć, że nie zostanie ona wykorzystana. Warto zastanowić się nad metodami zachęcającymi obywateli do uczestnictwa w wyborach i przeprowadzić w tym zakresie odrębne badania.

\section{Bibliografia}

ALBIN Krzysztof, 2000, Reklama: przekaz, odbiór, interpretacja, Warszawa/Wrocław.

BARAŃSKA Marzena, 2011, Reklama i jej ograniczenia. Standardy europejskie a prawo polskie, Warszawa.

BENEDIKT Antoni, 2004, Reklama jako proces komunikacji, Wrocław.

BRALCZYK Jerzy, 2003, O języku polskiej polityki lat osiemdziesiątych i dziewięćdziesiątych, Warszawa.

BRALCZYK Jerzy, 2004, Język na sprzedaż, Gdańsk.

CIALDINI Robert, 1999, Wywieranie wpływu na ludzi. Teoria i praktyka, przeł. B. Wojciszke, Gdańsk.

\footnotetext{
${ }^{6}$ http://www.infor.pl/prawo/wybory/prezydenckie/686946,Pierwsze-powszechne-wybory-prezydenckie.html (dostęp: 9.09.2017).

7 http://prezydent2015.pkw.gov.pl/319_Pierwsze_glosowanie (dostęp: 9.09.2017).

8 Ibidem.

9 Opis przebiegu badań przedstawił Dariusz Doliński (zob. Doliński 2010: 258-259).
} 
DENNISOn Dell / ToBeY Linda, 1994, Podręcznik reklamy. Jak zdobyć rozgłos, nie wydając fortuny na reklamę, przeł. Mulak M, Lublin.

DOBEK-OSTROWSKA Bogusława, 2005, Profesjonalizacja kampanii wyborczych we współczesnym świecie i jej konsekwencje, w: Dobek-Ostrowska B. (red.), Kampania wyborcza: marketingowe aspekty komunikowania politycznego, Wrocław, s. 11-33.

DOBEK-OstRowsKa Bogusława, 2006, Komunikowanie polityczne i publiczne: podręcznik akademicki, Warszawa.

DoBEK-OSTROWSKA Bogusława / WISZNIOWSKI Robert, 2002, Teoria komunikowania publicznego i politycznego: wprowadzenie, Wrocław.

DoLIŃSKI Dariusz, 2010, Psychologiczne mechanizmy reklamy, Gdańsk.

FILIPIAK Marian, 2003, Homo communicans: wprowadzenie do teorii masowego komunikowania, Lublin.

JACHNIS Anna / TerelaK Jan, 1998, Psychologia konsumenta reklamy, Bydgoszcz.

JANISZEWSKA Karolina / KALL Jacek, 2012, Strategia reklamowa: praktyczny poradnik dla menedżerów marki, Warszawa.

JEZIŃSKI Marek, 2005, Wizerunek polityczny jako element strategii wyborczej, w: Dobek-Ostrowska B. (red.), Kampania wyborcza: marketingowe aspekty komunikowania politycznego, Wrocław, s. 115-132.

KAMPKA Agnieszka, 2009, Perswazja w języku polityki, Warszawa.

KŁosiŃSKA Katarzyna, 2004, Rola procesów nominacyjnych w tworzeniu opozycji „my”/,oni” w języku polityki po 1989 roku, w: Krzyżanowski P./Nowak P. (red.), Manipulacja w języku, Lublin, s. 115-121.

KOCHAN Marek, 2002, Slogany w reklamie i polityce, Warszawa.

KowAL-OrCZYKowsKa Anna, 2010, Skuteczność reklamy, w: Kowalska E./Kowalski M. (red.), Reklama w społeczeństwie informacyjnym: konteksty społeczno-edukacyjne, Tychy, s. 35-64.

KUŚMIERSKI Stanisław, 1996, Reklama jest sztuką, Warszawa.

LEWIŃSKI Piotr, 2008, Retoryka reklamy, Wrocław.

ŁAZIŃSKI Marek, 2006, O Panach i Paniach. Polskie rzeczowniki tytularne i ich asymetria rodzajowo-płciowa, Warszawa.

ŁYSAKOWSKI Tomasz, 2005, Wpływowe osoby. Gramatyka i perswazja, Warszawa.

MURDOCH Anna, 2004, Kreatywność w reklamie, Warszawa.

NADOLSKA Katarzyna, 2011, Potrzeby psychiczne człowieka a reklama, Poznań/Opole.

TOKARZ Marek, 2006, Argumentacja, perswazja, manipulacja, Gdańsk.

WISZNIOWSKI Robert, 1999, Reklama polityczna a komunikowanie masowe, w: Dobek-Ostrowska B. (red.), Studia z teorii komunikowania masowego, Wrocław, s. 82-111.

\section{Strony internetowe}

Strona internetowa Infor, http:/www.infor.pl/prawo/wybory/prezydenckie/686946, Pierwsze-powszechne-wybory-prezydenckie.html.

Strona internetowa Kampanii negatywnej, http:/www.kampanianegatywna.pl/ wybory/18-haslawyborcze-kandydatow-na-prezydenta-polski-1990-2015.html.

Strona internetowa Marketingu w polityce, http://www.marketingwpolityce. zgora.pl/haslo.html.

Strona internetowa Państwowej Komisji Wyborczej, http://prezydent2015.pkw.gov.pl.

Strona internetowa SE, http://www.se.pl/wiadomosci/polityka/wszyscy-kandydaci-na-prezydentapolski-pelna-lista_584754.html. 